\title{
IMPLEMENTASI KEBIJAKAN KETERBUKAAN INFORMASI PUBLIK PADA PEMERINTAH PROVINSI JAWA BARAT
}

\author{
Diah Fatma Sjoraida \\ Fakultas Ilmu Komunikasi Universitas Padjadjaran \\ E-mail: diahfatmasjoraida@yahoo.co.id
}

\begin{abstract}
ABSTRAK. Dalam rangka implementasi kebijakan keterbukaan informasi public (UU Nomor 14 tahun 2008), Pemerintah Provinsi Jawa Barat membentuk Pejabat Pengelola Informasi dan Dokumentasi (PPID) dan Komisi Informasi Daerah (KID) dilingkungan Pemerintah Provinsi Jawa Barat. Meskipun demikian, masyarakat tidak puas atas pelayanan informasi yang diberikan, hal ini terlihat dari tingginya sengketa informasi publik di Jawa Barat.Penelitian ini bertujuan untuk mengetahui faktor-faktor lemahnya implementasi kebijakan tersebut. Metode yang digunakan dalam penelitian ini adalah metode kualitatif eksplanatif. Dari hasil penelitian diperoleh temuan mengenai faktor yang menyebabkan implementasi kebijakan KIP tidak berjalan efektif, yaitu: (1) struktur organisasi dan kewenangan pelaksana yang tidak memadai; (2) sosialisasi pelaksanaan kebijakan kepada target sasaran (masyarakat) tidak terlaksana dengan baik dan luas; (3) Program aksi yang tidak menyeluruh dan lengkap sesuai dengan UU; (4) Sumber daya yang tidak cukup membiayai kegiatan operasional; serta (5) pemahaman kebijakan keterbukaan informasi publik belum membuka mindset ketertutupan sehingga atmosfer keterbukaan menjadi tidak terlaksana dengan baik sebagaimana yang diharapkan. Saran yang dapat diajukan pada penelitian ini adalah (1) perlu dibentuk struktur organisasi khusus dengan membentuk PPID utama, sekretaris PPID, dan PPID pembantu sehingga pelayanan informasi publik lebih sistematis, terkoordinasi dan sinergis; (2) melakukan sosialisasi efektif kepada masyarakat mengenai mekanisme dan tata cara permohonan informasi publik; (3)Meningkatkan sumber daya.
\end{abstract}

Kata Kunci: Implementasi kebijakan, keterbukaan informasi publik, sengketa informasi

\section{POLICY IMPLEMENTATION OF PUBLIC INFORMATION TRANSPARENCY IN PROVINCIAL GOVERNMENT OF WEST JAVA IN 2012"}

\begin{abstract}
West Java Provincial Government established Organizing Official of Information and Documentation (or PPID, stands for Pejabat Pengelola Informasi dan Dokumentasi) and Regional Information Commission (or KID, stands for Komisi Informasi Daerah) under the Law no 14, year 2008 of implementation of public information openness. Nevertheless, Society is considered to be unsatisfied with the service of information, with the high number of public information dispute in West Java Province as prove of this low number of satisfaction. This research aims to recognize the factors that weaken the implementation of the policy. Method used in this research is qualitative explanatory. The finding of this research are factors that lead to ineffective KIP's policy, which will be as follow: (1) Inadequate organization structure and authority of implementers of the policy, (2) Socialization of policy implementation is not proficiently and widely organized for the target audience (society), (3) Action programs are not thoroughly and completely done according to law, (4) Insufficient resources to fund the operational activities, (5) The acknowledgement of public information openness is yet to unlock the closeness mindset, in which the openness atmosphere expected has not reach the goals. The suggestions from the findings of this research are: (1) Establish us special organization structure, (2) Implementing effective socialization to public on mechanism and procedure of public information request, (3) Increasing the resources, (4) brainstorming the official's way of thinking on public information openness.
\end{abstract}

Key words: Policy implementation, public information openness, information dispute

\section{PENDAHULUAN}

Bergulirnya reformasi telah membawa perubahan paradigma dalam sistem pemerintahan di Indonesia, dimana transparansi sebagai salah satu aspek tata kelola pemerintahan yang baik (good governance) menuntut penyelenggaraan pemerintahan yang semakin terbuka. Prinsip transparansi menjadi semangat bagi negara demokrasi dengan mengakui kedaulatan rakyatnyauntuk terlibat dalam setiap pengambilan keputusan, pelaksanaan maupun melakukan kontrol sosial dalam proses penyelenggaraan pemerintah untuk melayani kepentingan publik dan melaksanakan pembangunan. Melalui semangat keterbukaan (transparansi), negara memberikan ruang kepada publik untuk dapat mengakses informasi-informasi terkait kepentingan publik yang dikuasai pemerintah. Melalui semangat transparansi ini juga menuntut penyelenggaraan pemerintahan yang bersih, transparan, dan akuntabel.

Setiap warga negara Indonesia dijamin oleh konstitusi (UUD 1945) untuk berkomunikasi dan bebas mengakses informasi. Atas dasar ketetapan dalam UUD tersebut itulah maka pemerintah menerbitkan UU Nomor 14 Tahun 2008 tentang keterbukaan informasi publik (UU KIP) sebagai komitmen pemerintah untuk membuka pintu masuk era keterbukaan publik di Indonesia sekaligus sebagai dasar pelibatan publik untuk mengetahui proses dan alasan pengambilan keputusan yang menyangkut kehidupan dan kepentingan publik, proses pelaksanaan maupun evaluasi praktik penyelenggaraan pemerintahan di setiap tingkatan mulai dari pemerintah pusat sampai ke daerah. Agar pelaksanaan UU KIP berjalan dengan baik, setiap lini 
birokrasi pemerintah baik pusat terutama didaerah harus memiliki Pejabat Pengelola Informasi Daerah (PPID) serta membentuk Komisi InformasiDaerah (KID).

Menindaklanjuti UU KIP, Pemerintah Provinsi Jawa Barat merespon dengan membentuk KID dan PPID yang menangani pelaksanaan pelayanan informasi dan keterbukaan informasi publik di lingkungan Pemerintah Provinsi Jawa Barat. Dalam pelaksanaan UU KIP ini, Pemerintah Provinsi Jawa Barat memperoleh penghargaan sebagai badan publik terbaik dalam pelaksanaan keterbukaan informasi publik di tahun 2011 dan 2012. Meskipun Pemerintah Provinsi Jawa Barat memperoleh penghargaan sebagai badan public terbaik dalam melaksanaan keterbukaan informasi, namun sengketa informasi publik di Jawa Barat mencapai 250 kasus, masuk kategori tertinggi dibandingkan dengan provinsi lainnya di Indonesia. ${ }^{1}$ Bahkan, kecenderungan konflik/sengketa informasi di Jawa Barat mengalami peningkatan dalam kurun waktu tersebut.Adanya sengketa informasi tersebut menunjukan bahwa pelayanan dan keterbukaan informasi publik di Provinsi Jawa Barat belum berjalan sebagaimana mestinya.Penelitian ini penting dilakukan untuk mengetahui mengapa sengketa informasi di Jawa Barat masih tinggi serta factor-faktor yang mempengaruhi lemahnya implementasi kebijakan keterbukaan informasi publik. Rumusan masalah pada penelitian adalah sebagai berikut :

1. Bagaimana proses dan faktor yang mempengaruhi implementasi kebijakan Keterbukaan Informasi Publik pada Pemerintah Provinsi Jawa Barat?

2. Bagaimana sengketa informasi publik yang terjadi pada Pemerintah Provinsi Jawa Barat?

Kebebasan memperoleh informasi publik (public access to information) menjadi kebutuhan bagi semua elemen masyarakat karena menjadi salah satu prasyarat dan pondasi untuk menciptakan pemerintahan terbuka (open government) dalam sebuah tata kelola pemerintahan yang baik (good governance). Hal ini seperti pendapat yang dinyatakan oleh Rodney A. Smollar (1992: 12), berikut :

"A society that wishes to adopt openness as a value of overarchingsignificance will not merely allow citizen a wide range of individualexpressive freedom, but will go on step further and actually open up thedeliberate processes of government itself to the sunlight of public scrunity. Ina truly open culture, the normal rule is that government does not conductthe business of the people behind closed door. Legislative, administrative, and judicial proceedings should - as a matter of routine-be open to thepublic.

Tata kelola yang baik memiliki sejumlah indikator antara lain keterbukaan, partisipasi, akuntabilitas, efektivitas, dan koherensi. Menurut Mas Achmad Santosa (2011: 22), pemerintahan yang terbuka mensyaratkan adanya jaminan atas lima hal, yaitu:

\footnotetext{
1. Republika, 27 Juni 2012, "Kasus Sengketa Informasi Jabar Tertinggi"
}

a. hak untuk memantau perilaku pejabat publik dalam menjalankan peran publiknya;

b. hak untuk memperoleh informasi;

c. hak untuk terlibat dan berpartisipasi dalam proses pembentukan kebijakan publik;

d. kebebasan berekspresi yang antara lain diwujudkan dalam kebebasan pers; dan

e. hak untuk mengajukan keberatan terhadap penolakan atas keempat hak terdahulu.

Di Indonesia, pemberlakuan kebijakan keterbukaan informasi publik (Undang-Undang No. 14 Tahun 2008) merupakan suatu paradigma baru dalam kepemerintahan. Diterbitkannya undang-undang keterbukaan informasi publik sebagai upaya perbaikan diri pemerintah dan untuk memperoleh kembali kepercayaan dari masyarakat terkait informasi mengenai kinerja lembaga-lembaga pemerintahan.UU KIP merumuskan secara rinci mengenai cara-cara pelaksanaan keterbukaan informasi publik. dalam ketentuan umum UU KIP yang dimaksud informasi publik adalah informasi yang dihasilkan, disimpan, dikelola, dikirim, dan/atau diterima oleh suatu badan publik yang berkaitan dengan penyelenggara dan penyelenggaraan negara dan/atau penyelenggara dan penyelenggaraan badan publiklainnya yang sesuai dengan undang-undang ini serta informasi lain yang berkaitandengan kepentingan publik.

Pelaksanaan UU KIP harus berpegang pada prinsip/asas bahwa (a) Setiap Informasi Publik bersifat terbuka dan dapat diakses oleh setiap PenggunaInformasi Publik; (b) informasi Publik yang dikecualikan bersifat ketat dan terbatas; (c) setiap Informasi Publik harus dapat diperoleh setiap Pemohon Informasi Publik dengancepat dan tepat waktu, biaya ringan, dan cara sederhana; (d) informasi Publik yang dikecualikan bersifat rahasia sesuai denganUndang-Undangkepatutan, dan kepentingan umum didasarkan pada pengujian tentang konsekuensi yang timbul apabila suatu informasi diberikan kepada masyarakat serta setelahdipertimbangkan dengan saksama bahwa menutup Informasi Publik dapat melindungikepentingan yang lebih besar daripada membukanya atau sebaliknya.

Namun dalam implementasi UU keterbukaaan informasi publik tidak selamanya berjalan secara efektif dan mencapai tujuan dari kebijakan. Dalam implementasi kebijakan keterbukaan informasi publik tentu banyak syarat, kondisi dan faktor yang mempengaruhi efektif tidaknya implementasi dari kebijakan tersebut. Hoogerwerf (1983:157-161) mengatakan bahwa kebijakan memiliki unsur-unsur kebijakan, yakni: (a) adanya program aksi; (b) target group; dan (c) unsur pelaksana.

Brian W.Hogwood dan Lewis A.Gunn (dalam Nugroho, 2008:630-632), mengatakan bahwa unsur-unsur untuk melaksanakan kebijakan tidak cukup dengan 3 (tiga) unsur seperti yang dinyatakan oleh Hoogerwerf diatas. Unsur-unsur kebijakan juga menurut Brian W.Hogwood dan Lewis A.Gunn mensyaratkan adanya (1) sumber dayayang memadai, (2) pemahaman yang mendalam dan kesepakatan terhadap pencapaian tujuan; dan (3) adanya komunikasi dan koordinasi yang sempurna. 
Van Meter dan Van Horn (dalam Parsons, 2008: 482) mengatakan bahwa implementasi kebijakan ditunjukkan juga oleh adanya tingkat konsensus yang tinggi dan tidak membutuhkan banyak perubahan. Tingginya tingkat konsensus diantara pelaksana kebijakan maka implementasi kebijakan tersebut akan lebih sukses. Disinilah dibutuhkan mentalitas dari petugas yang menerapkan hukum atau kebijakan tersebut.Para petugas hukum (secara formal) yang mencakup hakim, jaksa, polisi, dan sebagainya harus memiliki mental yang baik dalam melaksanakan (menerapkan) suatu peraturan perundang-undangan atau kebijakan. Sebab apabila terjadi yang sebaliknya, maka akan terjadi gangguan-gangguan atau hambatanhambatan dalam melaksanakan kebijakan atau peraturan hukum.

Pendapat dari Hoogerwerf (1983:157-161) bahwa unsur-unsur penting dari implementasi kebijakan meliputi (1) program aksi; (2) target group (kelompok sasaran); dan (3) unsur pelaksana. Kemudian unsur-unsur kebijakan sebagaimana yang diuraikan oleh Hoogerwerf melengkapi pengetahuan tentang unsur-unsur kebijakan berdasarkan pendapat dari Brian W.Hogwood, Lewis A.Gunn; dan Gordon (1986).

Unsur-unsur kebijakan tidak saja dirumuskan dan dilaksanakan untuk mendukung pelaksanaan kebijakan secara tepat.Keberhasilan implementasi kebijakan informasi publik juga dipengaruhi oleh faktorfaktor diluar unsur-unsur kebijakan tadi.Grindle (1980: 9-11) menjelaskan faktor-faktor yang menyebabkan keberhasilan impelemntasi kebijakan yang meliputi variabel isi kebijakan (content of implementation) dan variabel lingkungan kebijakan (context of implentation). Variabel isi kebijakan (content of implementation) mencakup: (1 ) sejauh mana kepentingan kelompok sasaran atau target groups termuat dalam isi kebijakan. Apakah kebijakan keterbukaan informasi publik dapat melindungi hak-hak dari kelompok sasaran baik hak akses informasi masyarakat serta hak perlindungan hukum bagi pemerintah; (2) jenis manfaat yang diterima olehtarget groupsdari penerapan kebijakan keterbukaan informasi tersebut; (3) sejauh mana implementasi kebijakan informasi publik dapat menghasilkan perubahan yang di inginkan seperti terciptanya masyarakat informatif dan transparansi pemerintahan. Bagaimanapun suatu program kebijakan yang bertujuan mengubah sikap dan prilaku kelompok sasaran relatif lebih sulit untuk diimplementasikan; (4) apakah perumusan program aksi kebijakan informasi publik sudah tepat dilaksanakan; (5) kejelasan unsur pelaksana dan kewenangan dalam pelaksanaan kebijakan; dan (6) apakah sebuah program kebijakan keterbukaan informasi publik didukung oleh sumber daya yang memadai.

Variabel lingkungan kebijakan (context of implentation) mencakup : (1) seberapa besar kekuasaan, kepentingan, dan strategi yang dimiliki oleh para aktor yang terlibat dalam implementasi kebijakan keterbukaan informasi publik; (2) karakteristik institusi dan rejim yang sedang berkuasa ketika kebijakan informasi publik tersebut diterapkan; (3) tingkat kepatuhan dan responsivitas kelompok sasaran dalam mendukung implementasi kebijakan.

Berdasarkan kerangka berfikir analisis implementasi kebijakan keterbukaan informasi publik dalam memberikan pelayanan informasi publik pada Pemerintah Provinsi Jawa Barat, maka proposisi yang dapat dirumuskan dalam penelitian ini adalah :

1. Kebijakan keterbukaan informasi publik di Pemerintah Provinsi Jawa Barat dalam memberikan pelayanan publik diimplementasikan dengan baik apabila sudah berwujud dalam bentuk program aksi kegiatan, memiliki kelompok target sasaran, adanya unsur pelaksana kegiatan, sumber-sumber daya dan kesamaan pemahaman dalam menjalankan mandat dan tujuan kebijakan.

2. Sengketa informasi publik terjadi apabila unsur-unsur implementasi kebijakan tidak menjalankan fungsinya dengan baik.

\section{METODE}

Metode penelitian termasuk pada kategori penelitian kualitatif yang dilakukan untuk mengkaji dan menguraikan proses, serta aktivitas yang terjadi yang berkaitan dengan implementasi kebijakan keterbukaan informasi publik di Provinsi Jawa Barat mulai dari unsurunsur kebijakan, proses pelaksanaan kebijakan, hasil yang dicapai sampai kepada analisis faktor-faktor apa saja yang mempengaruhi pelaksanaan kebijakan. Data yang digunakan adalah data primerdan data sekunder. Data primer diperoleh melalui informan dan narasumber yang terdiri dari para implementor kebijakan yaitu pejabat struktural (PPID, staf kehumasan, staf diskominfo, komisioner KID) serta kelompok sasaran (target group) yakni lembaga-lembaga terkait dan kelompok kepentingan masyarakat.

\section{HASIL DAN PEMBAHASAN}

Sejak diberlakukan UU No. 14 Tahun 2008 selanjutnya disebut dengan UU KIP, Pemerintah Provinsi Jawa Barat merespon kebijakan tersebut dengan menerbitkan Keputusan Gubernur Provinsi Jawa Barat Nomor 489/ Kep.487-Diskominfo/2010 untuk membentuk Pejabat Pengelola Informasi dan Dokumentasi (PPID) sebagai unsur pelaksana kebijakan keterbukaan informasi publik. Pelaksanaan keterbukaan informasi publik oleh Pemerintah Provinsi Jawa Barat lebih memilih pola desentralisasi. Dengan pola ini, Pemerintah Provinsi Jawa Barat tidak membentuk PPID Provinsi, melainkan hanya membentuk PPID yang berada di tiap-tiap OPD (Organisasi Pemerintah Daerah). OPD tersebut dapat berbentuk sekretariat daerah, dinas-dinas, badan maupun lembaga. Setiap PPID dijabat oleh sekretaris masing-masing OPD, yang merupakan pejabat struktural yang melaksanakan fungsi kehumasan. Alasan diterapkannya pola desentralisasi ini agar setiap permohonan dan pelayanan informasi publik yang diminta masyarakat dapat langsung 
ditangani oleh masing-masing OPD, sehingga dapat memberikan pelayanan secara cepat, tepat dan mudah kepada masyarakat.

Selain membentuk PPID, Pemerintah Provinsi Jawa Barat juga membentuk Komisi Informasi Daerah (KID) Provinsi yang dilantik oleh Gubernur Jawa Barat pada 29 April 2011, berdasarkan Keputusan Gubernur Provinsi Jawa Barat Nomor: 489/Kep.486-Diskominfo/2010. Komisioner KID Provinsi semuanya berjumlah 5 (lima) orang yang terdiri dari unsur pemerintah dan masyarakat. Dalam pelaksanaan tugasnya, KID dibantu oleh sekretariat KID yang terdiri dari aparat pegawai negeri sipil (PNS). KID bertugas menetapkan kebijakan-kebijakan umum, aturan pelaksana dan aturan teknis, melaksanakan monitoring dan evaluasi implementasi KIP di lingkungan Provinsi Jawa Barat, serta melakukan mediasi dan adjudikasi non litigasi (penyelesaian masalah di luar pengadilan) untuk menyelesaikan masalah sengketa informasi publik antara pemerintah provinsi Jawa Barat dengan masyarakat apabila ada gugatan sengketa informasi yang disampaikan masyarakat dan/atau organisasi masyarakat lainnya sebagai pemangku kepentingan.

Baik PPID maupun KID sebagai unsur pelaksana kebijakan keterbukaan informasi publik (KIP) dalam melaksanakan tugas dan fungsi masih belum optimal. Tidak optimalnya pelaksanaan tugas dan fungsi dari PPID karena PPID yang dijabat oleh sekretaris dinas/badan tidak dibantu pejabat fungsional yang khusus menangani urusan pelayanan informasi dan dokumentasi. Penugasan kepada sekretaris dinas/ lembaga sebagai PPID dirasakan cukup berat, karena harus melakukan banyak tugas seperti penyimpanan informasi dan dokumentasi, kategorisasi dan klasifikasi informasi, membangun sistem informasi, melayani permohonan informasi dan sengketa informasi publik. Padahal, PPID yang dijabat oleh sekretaris dinas ini juga melaksanakan fungsi-fungsi lain diluar urusan PPID. Oleh karena itu, sebagaimana pasal 13 ayat (2) UU KIP, PPID harus dibantu oleh aparat fungsional seperti pranata komputer, pranata humas dan arsiparis. Aparat fungsional sangat diperlukan agar pelayanan permohonan informasi dari masyarakat dapat terlaksana dengan baik. Pada tiap-tiap OPD, fungsi PPID masih dianggap fungsi sampingan dan tidak masuk dalam tupoksi OPD. Meskipun, tugas PPID menyita tenaga dan waktu namun sayangnya fungsi ini tidak masuk dalam perhitungan kinerja, sehingga aparat dan pejabat kurang termotivasi dalam melaksanakan fungsi dan tugas tersebut.

Komisi informasi Daerah (KID) Provinsi juga belum sepenuhnya menjalankan kewenangan dalam hal menyediakan dukungan kebijakan bagi Pemerintah Provinsi Jawa Barat yakni berupa kebijakan umum, petunjuk teknis pelaksanaan keterbukaan informasi publik, sebagaimana yang diamanatkan UU KIP. Meskipun dalam pelayanan informasi publik, KID Provinsi sudah berpegang pada Per-KI SLIP dan PPSIP ${ }^{2}$, namun KID Provinsi 2.Peraturan Komisi Informasi Standar Layanan Informasi Publik belum membuat petunjuk pelaksana dan petunjuk teknis pelayanan informasi publik yang disesuaikan dengan kondisi daerah di Provinsi Jawa Barat. KID juga hingga saat ini belum membantu PPID dalam penyusunan kategori dan klasifikasi informasi. Sehingga ketika terjadi sengketa informasi, terdapat perbedaan antara PPID dan KID, yang mana ketika PPID mengkategorikan suatu informasi sebagai informasi yang dikecualikan tetapi KID pada proses penyelesaian sengketa, informasi tersebut dikategorikan sebagai informasi yang terbuka dan dapat diakses setiap saat. Dengan demikian, harus ada kejelasan dan kesepakatan antara PPID dengan KID Provinsi terkait klasifikasi informasi tersebut. Perkembangan klasifikasi informasi pun harus selalu dipantau oleh KID Provinsi. Karena menurut Pasal 20 UU KIP, informasi yang dikecualikan tidak bersifat permanen. Artinya jika suatu saat disepakati dan tidak mengancam keamanan nasional, maka informasi yang semula dikecualikan bisa saja berubah menjadi informasi yang dapat diakses setiap saat.

Dalam hal metode pelaksanaan kebijakan KIP di Provinsi Jawa Barat yang menggunakan pola desentralisasi dimana pelayanan informasi publik langsung dilaksanakan oleh OPD masing-masing, dirasakan kurang efektif ketika sosialisasi di masyarakat berjalan kurang baik. Masyarakat yang tidak tersosialisasi dengan baik mengenai metode desentralisasi ini, umumnya mengajukan permohonan informasi langsung ke Gedung Sate dengan menghubungi Humas Setda Provinsi Jawa Barat. Meskipun permohonan informasi tersebut sudah disampaikan Humas Setda ke Diskominfo, kemudian dari Diskominfo baru disampaikan ke OPD terkait untuk ditindaklanjuti, namun bagi masyarakat yang tidak memahami, sering mengeluhkan bahwa permohonan informasi publik yang ditujukan kepada Pemerintah Provinsi Jawa Barat terkesan saling lempar tanggung jawab pelayanan informasi publik. Padahal apa yang dilakukan baik oleh Humas Setda maupun Diskominfo sudah tepat, karena kedua OPD ini tidak dapat memberikan informasi yang tidak mereka kuasai, karena jika tetap memberikan informasi yang tidak dikuasai yang sesungguhnya merupakan kewenangan OPD lain, maka jika dilakukan akan melanggar ketentuan UU KIP. Ketentuan ini sesuai dengan Pasal 6 Ayat (3) huruf (e) UU KIP yang menyatakan bahwa informasi publik tidak dapat diberikan oleh Badan Publik, apabila informasi publik yang diminta tersebut belum dikuasai atau didokumentasikan. Berdasarkan masalah diatas, terdapat kekurangan penerapan pola desentralisasi yaitu kurangnya sosialisasi dimasyarakat mengenai mekanisme permohonan informasi publik. Meskipun Pemerintah Provinsi Jawa Barat sudah mensosialisasikan tata cara permohonan informasi tetapi Pemerintah Provinsi Jawa Barat tidak menjelaskan daftar informasiinformasi publik apa saja yang tersedia di tiap-tiap OPD. Tersedianya daftar informasi publik di masing-masing OPD, menjadi pedoman/arahan bagi masyarakat untuk mengetahui permohonan informasi publik yang tersedia

(Per-KI SLIP) dan Prosedur Penyelesaian Sengketa Informasi Publik (PPSIP) 
disetiap OPD yang dituju.

Dalam melaksanakan suatu kebijakan, harus dirumuskan program aksi yang akan dijalankan agar tujuan dari kebijakan dapat tercapai. Program aksi yang harus dilakukan oleh Pemerintah Provinsi Jawa Barat terkait pelaksanaan keterbukaan informasi publik berupa pengumuman informasi publik yang dapat diakses masyarakat dengan cepat, tepat dan murah. Sebelum mengumumkan informasi publik, Pemerintah Provinsi Jawa Barat terlebih dahulu harus menyusun Daftar Informasi Publik, seperti Informasi yang tersedia setiap saat, Informasi yang diumumkan secara berkala, Informasi yang diumumkan secara serta merta, dan Informasi yang dikecualikan. Penyusunan daftar layanan informasi dan klasifikasi informasi publik sesungguhnya menjadi kewenangan PPID untuk membuatnya.Agar tidak terjadi kesalahan klasifikasi informasi publik, maka PPID terlebih dahulu harus melakukan uji konsekuensi publik (consequency harm test) dan uji kepentingan publik (public interest test) terhadap dokumen dan informasi-informasi tersebut.Setelah melakukan kedua uji ini barulah PPID dapat membuat klasifikasi informasi, mana informasi yang dapat disediakan setiap saat, informasi yang diumumkan secara berkala, informasi yang dikecualikan dan informasi yang tidak dapat diberikan karena diluar penguasaan badan publik yang bersangkutan. Kenyataanya, uji terhadap informasi publik tersebut tidak dilakukan oleh PPID di tiap-tiap OPD di lingkungan Pemerintah Provinsi Jawa Barat.Tidak adanya daftar layananan informasi dan klasifikasi informasi publik membuat pejabat dan aparat badan publik merasa bingung dan ragu-ragu untuk memberikan layanan informasi publik karena jika informasi yang diberikan tidak sesuai, pejabat atau aparat badan publik tersebut dapat dikenakan pasal 54 UU KIP, yang berkonsekuensi pada sanksi perdata maupun pidana. Menurut salah satu informan dari elemen masyarakat (LSM yang sering megajukan gugatan sengketa informasi kepada KID Provinsi) pemahaman badan publik Pemerintah Provinsi Jawa Barat mengenai implementasi UU KIP memang kurang baik, sehingga tidak mampu menganalisis kategori informasi yang dikecualikan maupun melakukan uji konsekuensi informasi. Padahal setiap melayani permohonan informasi, badan publik dalam mengambil keputusan harus mampu juga menelaah tujuan pemohon dalam meminta informasi.Oleh karena itu perlu adanya pendidikan dan sosialisasi mengenai pelaksanaan KIP secara reguler melalui bimtek maupun diklat PNS.

Program aksi lainnya yang harus dilakukan terkait pelaksanaan UU KIP ini adalah memberikan pelayanan informasi publik secara cepat, tepat dan mudah yang antara lain dilaksanakan dengan membangun sistem informasi melalui layanan web online (website), www. jabarprov.go.id yang dikelola oleh Dinas Komunikasi dan Informasi (Diskominfo). Dalam website tersebut berisi layanan informasi publik terkait kegiatan penyelenggaraan pemerintahan yang dapat diakses langsung oleh masyarakat.Membangun database informasi publik yang terhubung dengan website OPD-OPD yang didalamnya mengumumkan penyelenggaraan kegiatan OPD di lingkungan Provinsi Jawa Barat. Meskipun, Pemprov Jabar sudah membangun system informasi yang dapat diakses masyarakat, namun menurut organisasi Perkumpulan Inisiatif OPD-OPD di lingkungan Provinsi Jawa Barat nyatanya belum siap melaksanakan keterbukaan informasi publik. Pernyataan ini berdasarkan pada hasil penelitian organisasi Perkumpulan Inisiatif yang melakukan uji akses informasi publik terhadap 37 OPD di lingkungan Pemerintah Provinsi Jawa Barat sejak November 2010 sampai dengan April 2011. Dalam uji akses informasi, data akses informasi publik yang diminta berjumlah 15 data, diantaranya yaitu:

1. Dokumen Rencana Strategis;

2. Dokumen Rencana Kerja;

3. Dokumen Pelaksanaan Anggaran;

4. Dokumen Pelaksanaan Perubahan Anggaran, dan

5. Dokumen-dokumen lainnya.

Dari hasil uji akses informasi publik tersebut, ternyata hanya dua dinas yang memberikan informasi sesuai dengan yang dibutuhkan publik. Dinas yang dimaksud adalah Dinas Perindustrian dan Perdagangan Provinsi Jawa Barat dan Dinas Perhubungan, sedangkan dinas lainnya tidak memberikan data apapun yang diminta. Dari 37 OPD yang diuji, 12 OPD merespon permintaan akses data tersebut. Adapun respon ke-12 OPD tersebut adalah 6 (enam) OPD menolak dimintai data dan 6 (enam) OPD lainnya menyerahkan data informasi tetapi tidak lengkap. Sedangkan 25 OPD sisanya tidak memberikan respon apapun.6 (enam) OPD yang menyerahkan data informasi namun tidak lengkap tersebut seperti tercantum pada tabel 1 .

Tabel 1. Daftar Badan Publik Pemerintah Provinsi Jabar yang Merespon Permintaan Informasi

\begin{tabular}{|c|c|c|}
\hline No & Nama OPD & Keterangan \\
\hline 1 & $\begin{array}{l}\text { Dinas Perhubungan Jawa } \\
\text { Barat }\end{array}$ & \multirow{2}{*}{$\begin{array}{l}\text { Nyaris memenuhi dan } \\
\text { memberikan data secara } \\
\text { lengkap }\end{array}$} \\
\hline 2 & $\begin{array}{l}\text { Dinas Perindustrian dan } \\
\text { Perdagangan Jawa Barat }\end{array}$ & \\
\hline 3 & $\begin{array}{l}\text { Dinas Perikanan dan } \\
\text { Kelautan Jawa Barat }\end{array}$ & $\begin{array}{l}\text { Tidak memberikan data scr } \\
\text { lengkap }\end{array}$ \\
\hline 4 & $\begin{array}{l}\text { Badan Koordinasi Promosi } \\
\text { dan Penanaman Modal } \\
\text { Daerah }\end{array}$ & \\
\hline 5 & Sekretariat KPID & \\
\hline 6 & $\begin{array}{l}\text { Dinas Komunikasi dan } \\
\text { Informasi Jawa Barat }\end{array}$ & $\begin{array}{l}\text { Hanya memberikan } 2 \text { dari } \\
15 \text { data yang diminta }\end{array}$ \\
\hline
\end{tabular}

Sumber : Hasil Penelitian Uji Akses Informasi yang dilakukan Peneliti Perkumpulan Inisiatif, Tahun 2010-2011, Seputar Indonesia, 29 September 2011

Menurut informasi dalam wawancara yang diperoleh dari Diskominfo Jabar, ketersediaan informasi tentang Jawa Barat dan program-program Pemerintah Provinsi Jawa Barat sebagaimana yang diminta oleh pemohon informasi, seharusnya memang sudah menjadi tugas dan fungsi PPID di lingkungan Pemerintah Provinsi Jawa Barat maupun Diskominfo Jawa Barat. Namun PPID Diskominfo Jawa Barat mengalami keterbatasan anggaran yang tersedia sehingga pemenuhan hak masyarakat untuk memperoleh keterbukaan informasi belum maksimal. Masyarakat menerima informasi masih 
terbatas pada keberadaan website dan pelayanan desk (bila permohonan informasi tersebut diajukan masyarakat) ke kantor Diskominfo Jawa Barat.Padahal pembentukan PPID atas pertimbangan, bahwa untuk tersedianya informasi yang dapat dipertanggungjawabkan perlu didukung dokumentasi yang lengkap, akurat, dan faktual; keterbukaan informasi publik sebagai sarana dalam mengoptimalkan partisipasi dan pengawasan publik dalam proses penyelenggaraan pemerintahan.

Kesulitan lainnya yang dihadapi oleh Diskominfo yaitu meskipun website Provinsi Jawa Barat sudah terhubung (link) dengan website maupun email yang ada di OPD, namun OPD-OPD yang bersangkutan jarang sekali melakukan updating (pemuktahiran) data dan informasi yang seharusnya diumumkan dan diketahui oleh publik.Untuk sementara ini layanan informasi tentang kinerja OPD yang banyak dilakukan berdasarkan permintaan langsung dan tertulis dari masyarakat, sedangkan informasi yang disampaikan secara online belum sepenuhnya memenuhi keinginan masyarakat maupun ketentuan yang diamanatkan dalam UU KIP.

Hogwood dan Gunn mengatakan bahwa salah satu dari sekian banyak syarat berhasilnya implementasi kebijakan adalah adanya sumber-sumber daya dan keterpaduan dari sumber-sumber yang diperlukan. Oleh karena itu, implementasi kebijakan publik akan melibatkan berbagai sumber yang diperlukan, baik dalam konteks sumber daya maupun sumber aktor (dalam Parsons, 2008: 631). Faktanya di Pemerintah Provinsi Jawa Barat menunjukkan adanya kesenjangan mutu pelayanan publik di bidang akses informasi. Hal itu disebabkan sarana dan prasarana yang belum memadai, sumber daya manusia yang masih terbatas, dan praktek manajemen sistem layanan informasi publik yang belum terpadu.

Dalam hal ketersediaan sumber daya anggaran kegiatan operasional, .OPD-OPD di lingkungan Pemerintah Provinsi Jawa Barat memang tidak memiliki anggaran khusus pelaksanaan urusan pelayanan informasi publik. Padahal anggaran tersebut dibutuhkan untuk membiayai kegiatan operasional misalnya untuk melayani permintaan salinan informasi publik. Meskipun dalam UU KIP, badan publik dibenarkan untuk menetapkan standar biaya atas layanan informasi publik kepada pemohon (misalnya biaya salinan dokumen informasi publik), namun masing-masing OPD di lingkungan Provinsi Jawa Barat ragu-ragu dan belum menetapkan standar biaya layanan terkait salinan informasi publik tersebut. Karena dikhawatirkan penetapan standar biaya, tidak bisa diterima dan dipahami oleh masyarakat.Untuk itu menutupi kekurangan, Pemerintah Provinsi Jawa Barat -melalui Diskominfo- melakukan sosialisasi eksternal terkait pelaksanaan UU KIP.Media pengumuman informasi yang digunakan hanya melalui situs resmi Pemerintah Provinsi Jawa Barat. Pemerintah Provinsi Jawa Barat tidak melakukan sosialisasi dan penyampaian informasi secara khusus di media massa karena tidak adanya anggaran sosialisasi di media massa.

Dalam hal pemanfaatan website resmi Pemerintah Provinsi Jawa Barat, ternyata tidak banyak OPD-
OPD yang memanfaatkan link website tersebut untuk mengumumkan informasi-informasi yang seharusnya dapat diakses masyarakat, baik informasi yang wajib diumumkan secara berkala maupun informasi yang wajib diumumkan setiap saat. Terkait dengan masalah tersebut, menurut salah satu informan penelitian, pelaksana di tiaptiap OPD belum semuanya dilengkapi dengan peralatan teknologi informasi dan komunikasi, padahal pelayanan informasi publik sangat membutuhkan kesediaan sarana teknologi informasi dan komunikasi (TIK). Pemanfaatan TIK dalam manajemen pelayanan publik, meskipun sudah dimanfaatkan tapi masih dalam lingkup terbatas. Ketertinggalan Pemerintah Provinsi jawa Barat dalam pendayagunaan TIK menjadi isu penting sebagai masalah pelaksanaan kebijakan keterbukaan informasi publik ini. Oleh karena itu, penyelenggaraan manajerial pemerintahan yang berbasis pada teknologi informasi dan komunikasi merupakan langkah penting untuk meningkatkan efektifitas dan efisiensi pelayanan publik serta peningkatan transparansi dan akuntabilitas pemerintah.

Permasalahan adanya sengketa informasi dalam pelayanan informasi publik di Provinsi Jawa Barat disinyalir karena pemerintah lamban merespon, mengumumkan informasi yang tidak mutakhir, bahkan adanya fakta pejabat dan parat pemerintah di Provinsi Jawa Barat mengabaikan permohonan masyarakat terhadap informasi publik menunjukkan lemahnya pemahaman dan kesadaran aparat pemerintah dan pejabat pelaksana (PPID) di Lingkungan Pemerintah Provinsi Jawa Barat terhadap substansi, asas dan tujuan UU KIP. UU KIP menjelaskan bahwa pada dasarnya informasi bersifat terbuka dan dapat diakses oleh masyarakat secara luas. Masih adanya aparat dan badan publik pemerintah yang tidak menyadari arti penting keterbukaan informasi publik ini dengan sendirinya menunjukkan ketidaksiapan secara mental, karena pemerintah dan badan publik pemerintah di Indonesia umumnya sudah terbiasa dengan kultur ketertutupan. Pemahaman ini menunjukkan belum adanya atmosfer keterbukaan yang menjadi komitmen pejabat pemerintah dalam implementasi KIP.

Selain itu, adanya 'ketakutan' dari pihak pemerintah Provinsi Jawa Barat bahwa keterbukaan informasi publik akan berakibat buruk kepada upaya penyalahgunaan informasi seperti upaya pencemaran namabaik, penipuan maupun pemerasan. Ketakutanini bukan tidak beralasan, karena memang pada faktanya, -berdasarkan hasil wawancara-, ada beberapa pihak pemohon informasi yang bersikap berlebihan untuk tujuan yang tidak baik. Sehingga motif permohonan informasi bukan untuk kepentingan kontrol kinerja publik melainkan cenderung untuk ditransaksikan. Sehingga isu keterbukaan informasi publik disikapi sangat hati-hati oleh Pemerintah Provinsi Jawa Barat. Dengan diberlakukannya kebijakan keterbukaan informasi publik ini, pemerintah bukan semakin terbuka melainkan terkesan menutup-nutupi dan sangat birokratis terhadap permohonan informasi publik yang diajukan masyarakat. Alasan 'ketakutan' sebagaimana yang dikemukakan diatas sebenarnya merupakan bentuk ketidaksiapan mental aparat dan 
pejabat terhadap upaya perubahan paradigma tata kelola pemerintahan (good governance) yang sangat menjunjung tinggi demokrasi, partisipasi publik dan keterbukaan (transparansi).

Seperti yang sudah dijelaskan, memang sejak diberlakukannya kebijakan keterbukaan informasi publik di Jawa Barat bukan berarti terbebas dari masalah implementasi kebijakan. Bahkan, di Jawa Barat justru menunjukkan adanya peningkatan yang signifikan terkait pelaksanaan kebijakan keterbukaan informasi publik tersebut. Peningkatan masalah implementasi kebijakan yakni semakin banyaknya keluhan masyarakat terhadap permohonan informasi publik yang disampaikan melalui gugatan sengketa informasi merupakan ironi karena bagaimanapun menurut Parsons, lahirnya kebijakan memiliki alasan atau argumen yang mengandung klaim bahwa pemilik kebijakan memahami persoalan beserta solusinya. Dengan adanya kebijakan justru mengarahkan kepada pemerintah dan masyarakat mengenai apa yang sesungguhnya terjadi dan apa yang seharusnya dilakukan. Apabila hakikat kebijakan ini sudah dipahami, dan dengan pelaksanaan kebijakan dapat menghasilkan solusi atas permasalahan, maka keberhasilan dari pelaksanaan kebijakan dapat menjadi dasar klaim bagi tercapainya legitimasi pemerintah (Parsons, 2008: 17).

Kesadaran aparat pemerintah Provinsi Jawa Barat untuk merubah mindset ketertutupan menjadi mindset transparansi melahirkan komitmen untuk mewujudkan dan melaksanakan kebijakan keterbukaan informasi publik baik oleh Pemerintah Provinsi maupun Pemerintah Kabupaten/Kota di seluruh wilayah Jawa Barat. Karena pelayanan informasi publik dan menegakkan keterbukaan informasi publik merupakan kewajiban bagi para penyelenggara negara dan badan-badan publik lainnya, maka konsekuensinya pada perubahan mindset birokrasi dan kultur birokrasi pemerintah, begitupula pula dengan struktur dan prosedur birokrasi dengan sendirinya harus berubah. Keterbukaan informasi publik ibarat pelumas yang akan mempercepat perubahan-perubahan di dalam tata kelola kepemerintahan yang baik yang harus dijalankan oleh birokrasi. Itulah makna penting dan strategis dari keterbukaan informasi bagi reformasi birokrasi yang sedang dijalankan. Perubahan yang signifikan dari hadirnya UU Keterbukaan Informasi publik adalah diujinya badanbadan publik pemerintah seiring dengan berjalannya waktu. Karena itu dibutuhkan publik yang proaktif yang terus menerus menagih janji kepada pemerintah untuk mengimplementasikan UU KIP tersebut. Hanya dengan cara demikian, cita-cita lahirnya masyarakat informasi yang kritis akan dapat diwujudkan dan manfaat UU KIP bagi kehidupan yang semakin demokratis.

Komitmen untuk melaksanakan dan memberikan pelayanan informasi publik yang sebaik-baiknya merupakan buah kesadaran pemerintah yang berangkat dari realitas bahwa yang paling bersentuhan dengan kepentingan publik adalah Pemerintah. Karena itu informasi yang dihasilkan, disimpan, dikelola, dikirim dan/atau diterima oleh suatu badan publik yang berkaitan dengan penyelenggaraan negara dan informasi lainnya yang berkaitan dengan kepentingan publik, menjadi kewajiban pemerintah yang paling utama dalam memberikan yang terbaik dalam pelayanan informasi publik. Dengan demikian dapat dikatakan bahwa intepretasi yang benar dari tujuan kebijakan keterbukaan informasi publik seharusnya dapat menghasilkan kesadaran bersama mengenai urgensi pencapaian tujuan pelaksanaan kebijakan. Kesadaran bersama di kalangan pemerintah Provinsi Jawa Barat tersebut akan menghasilkan suatu bentuk konsensus dan komitmen yang mempengaruhi konsistensi dalam bersikap, dan pada akhirnya membentuk budaya yang akan memperkuat organisasi pemerintah dan terlaksananya kebijakan secara efektif. Kesuksesan dari implementasi kebijakan ini sangat tergantung pada adanya tingkat konsensus yang tinggi dan tidak banyak membutuhkan perubahan (Parsons, 2008: 482).

Namun pelaksanaan kebijakan keterbukaan informasi publik nyatanya membutuhkan perubahan secara mendasar yakni perubahan mental berupa mindset dan culture set birokrasi pemerintah yang sudah lama terbiasa dengan budaya ketertutupan. Dengan demikian keberhasilan implementasi kebijakan keterbukaan informasi publik (UU KIP) sangat bergantung pada sejauh mana pemahaman, kesadaran yang mendalam dari para penguasa negara, birokrasi pemerintah sebagai pelaksana, para elit politik, yang akan menghasilkan kesepakatan dan konsensus terhadap pencapaian tujuan diberlakukannya kebijakan tersebut.

\section{SIMPULAN}

Berdasarkan hasil dan pembahasan penelitian dapat disimpulkan bahwa beberapa kekurangan dalam proses Implementasi Kebijakan Keterbukaan Informasi Publik (UU KIP) di Lingkungan Pemerintah Provinsi Jawa Barat diantaranya adalah (a) kesatuan koordinasi dan keseragaman pelayanan informasi, serta jaringan kerja sama di lembaga PPID di lingkungan Pemerintah Provinsi Jawa Barat belum terlaksana karena terhambat persoalan struktural; (b) aparat pelaksana kurang termotivasi karena urusan layanan informasi publik masih menjadi fungsi sampingan bukan fungsi utama di dalam tugas pokok dan fungsi Organisasi Perangkat Daerah (OPD) sehingga tidak ada reward berupa perhitungan kinerja.; (c) Target sasaran yakni masyarakat Jawa Barat masih belum memahami mekanisme permohonan informasi sehingga timbul persepsi bahwa Pemerintah Provinsi Jawa Barat lamban dalam merespon permohonan informasi publik, selain itu, OPD-OPD di Pemerintah Provinsi Jawa Barat enggan melayani permohonan informasi yang sering dijadikan modus 'pemerasan' atau pemanfaatan informasi diluar tujuan keterbukaan informasi publik; (d) Program aksi dalam implementasi kebijakan keterbukaan informasi publik (UU KIP) dilaksanakan dengan metode desentralisasi dengan tujuan agar pelayanan yang lebih tepat, cepat dan mudah. Namun pola desentralisasi tersebut mengakibatkan ketidak seragaman pelayanan informasi di masingmasing OPD; (e ) Sumber daya pelaksanaan PPID kurang memadai, tidak ada anggaran khusus pelaksanaan fungsi pelayanan informasi padahal juga memakan biaya diantaranya biaya koordinasi, pelayanan informasi dan 
sosialisasi; (f) belum seragamnya pemahaman aparat dalam melaksanakan keterbukaan informasi publik, sehingga beberapa informasi terkesan dirahasiakan atau ditutup-tutupi.

Berdasarkan simpulan penelitian dapat dirumuskan saran, agar implementasi kebijakan keterbukaan informasi publik dapat dilaksanakan dengan baik yakni Pemerintah Provinsi Jawa Barat perlu segera membentuk struktur organisasi yang permanen dalam pelaksanaan fungsi PPID dengan pola sentralisasi sehingga tercapai kesatuan koordinasi dan keseragaman pelayanan informasi, dan terjalinnya jaringan kerja sama lembaga PPID di lingkungan Pemerintah Provinsi Jawa Barat. SOTK OPD direvisi dengan memasukkan fungsi PPID/ pelayanan informasi kedalam tupoksi menjadi salah satu fungsi utama OPD. Pejabat Pengelola Informasi dan Dokumentasi (PPID) harus dilengkapi dengan aparat/ pejabat pelaksana fungsional seperti pranata komputer, humas dan arsiparis, sehingga layanan informasi publik menjadi profesional. Pemerintah Provinsi Jawa Barat perlu melaksanakan sosialisasi secara intensif yang ditujukan kepada masyarakat terkait mekanisme dan tata cara permohonan informasi publik. Kepala daerah Provinsi Jawa Barat mulai menanamkan kesamaan faham tentang pentingnya keterbukaan informasi publik dalam benak aparat, sehingga transparasi dan akuntabilitas dapat terwujud.

Untuk meminimalisir sengketa informasi publik, Pemerintah Provinsi Jawa Barat perlu segera melakukan uji konsekuensi dan uji kepentingan publik untuk merumuskan klasifikasi dan daftar layanan publik. Pengujian dilakukan melibatkan unsur pemerintah (OPD), masyarakat, akademisi, praktisi, dan komisi informasi. Perlu segera menyusun SOP layanan informasi publik yang disesuaikan dengan kondisi pada OPD masing-masing, serta memerintahkan dan mengawasi kerja aparat bawahannya untuk selalu melakukan pemuktahiran data dan informasi yang diumumkan ke website sesuai ketentuan Per-KI tentang SLPIP.
Proses pelaksanaan layanan informasi publik dapat terlaksana dengan baik apabila Pemerintah Provinsi Jawa Barat yaitu merubah mindset dan culterset yang menjunjung tinggi prinsip transparansi dan akuntabilitas dengan memahami bahwa di era keterbukaan, informasi yang menyangkut kehidupan publik pada dasarnya terbuka untuk diakses dan diumumkan kepada publik.

\section{DAFTAR PUSTAKA}

Gordon., I. and Lewis, J. 1986. Perspectives on Policy Analysis. Public Administration Bulletin, Vol. 25

Grindle. M. S. 1980. Politics and Policy Implementation in the Third World. Princenton University Press.

Meter, V dan Horn, V. 1974. Human Resource Champions. Boston: Harvard Business School Press.

Nugroho, R. 2008. Public Policy: Teori Kebijakan, Analisis Kebijakan, Proses Kebijakan, Perumusan, Implementasi, Evaluasi, Revisi, Risk Management Dalam Kebijakan Publik, Kebijakan sebagai The Fifth Estate, Metode Penelitian Kebijakan. PT. Elex Media Komputindo, Jakarta

Parsons, W. 2008. Public Policy: Pengantar Teori dan Praktik Analisis Kebijakan, Jakarta: Penerbit Kencana

Republika, 27 Juni 2012, Kasus Sengketa Informasi Jabar Tertinggi

Santosa, M.A. 2001. Good Governancedan Hukum Lingkungan, Jakarta: ICEL

Smollar, R.A. 1992. Free Speech in an Open Society, New York: Vintage Book,

Tribun Jabar, Kamis, 29 September 2011, Pemprov Jabar Belum Siap Terbuka

Seputar Indonesia, Kamis, 29 September 2011, Mayoritas Badan Publik Pemprov Tertutup 